\title{
Epidemiological survey of oral lesions diagnosed at a stomatology service.
}

\section{Estudo epidemiológico das lesões orais diagnosticadas em um serviço de estomatologia.}

\section{Etienny da Silva Arruda 1,a, Gesom Avohai Dias Sombra ${ }^{2, b}$, Juliana Vianna Pereira ${ }^{3, c}$, José Eduardo Gomes Domingues $^{3, d}$, Tânia Cristina Chicre Alcântara ${ }^{3, e}$, Nikeila Chacon de Oliveira Conde ${ }^{3, f}$.}

\section{RESUMO}

Objetivo: Determinar a prevalência de alterações de mucosa e lesões bucais diagnosticadas na Faculdade de Odontologia da Universidade Federal do Amazonas, Manaus - Brasil. Materiais e métodos: Estudo transversal, descritivo e retrospectivo, que analisou os prontuários de pacientes maiores de 18 anos atendidos entre 2010 e 2013. Foram coletados dados relacionados a presença de alterações de tecido mole, com ênfase em lesões de coloração branca, além de variáveis como idade, sexo, uso de medicações, doenças sistêmicas e hábitos deletérios. Os dados foram submetidos a análise descritiva e apresentados através de médias e desvio padrão por meio de tabelas. Resultados: Foram incluídos 82 prontuários, com prevalência do sexo feminino $(60,98 \%)$ e média de idade de 43,3 anos. Foram encontradas 307 alterações de mucosa bucal, e dentre estas 27,69\% consistiam em lesões de coloração branca. Grânulos de Fordyce (35,37\%), linha alba (15,85\%) e hiperqueratose focal $(9,76 \%)$ foram as alterações de coloração branca mais relatadas. Dentre as lesões com potencial de malignização, líquen plano, leucoplasia e queilite actínica estiveram presentes em menos de $5 \%$ dos achados, correspondendo a 2,6\% das alterações brancas encontradas. Conclusão: Os pacientes atendidos neste serviço de estomatologia possuíram alta prevalência de alterações em mucosa bucal, dentre elas, lesões de coloração branca. Certificado de Apreciação Ética nº 38861314.3.0000.5020.

Palavras-chave: manifestações bucais, mucosa bucal, prevalência.

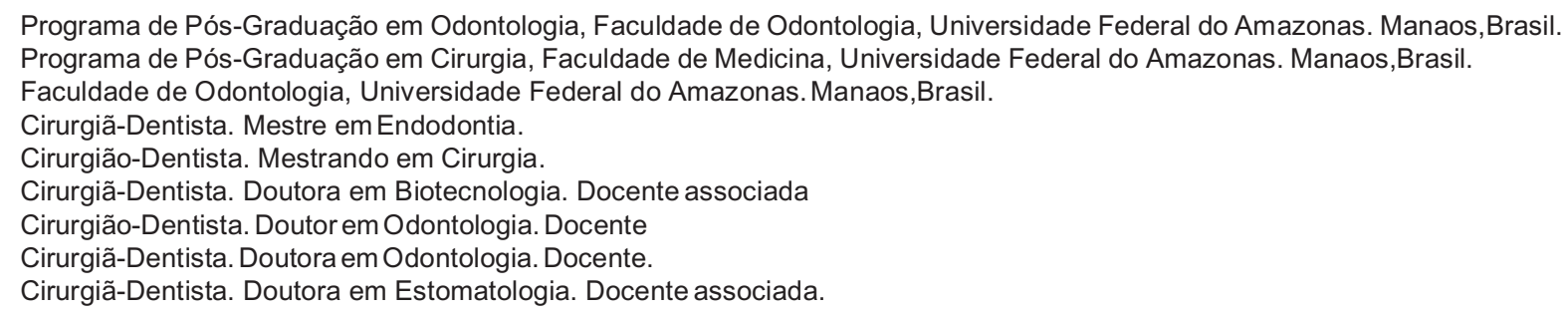




\begin{abstract}
Objective: To determine the prevalence of mucosal alterations and oral lesions diagnosed at the School of Dentistry, Federal University of Amazonas, Manaus-Brazil. Materials and methods: Cross-sectional, descriptive and retrospective study, which analyzed the medical records of patients over 18 years of age from 2010 to 2013. Data were collected related to presence of soft tissue alterations, with emphasis on white-colored lesions, as well as variables such as age, gender, use of medications, systemic diseases and deleterious habits. The data were submitted to descriptive analysis and presented by average and standard deviation by means of tables. Results: 82 medical records were included, with prevalence of the female $(60.98 \%)$ and mean age of 43.3 years. A total of 307 oral mucosa alterations were found and among these $27.69 \%$ consisted of white-colored lesions. Fordyce granules $(35.37 \%)$, linea alba (15.85\%) and focal hyperkeratosis $(9.76 \%)$ were the most reported whitecolored alterations. Among the lesions with malignant potential, lichen planus, leukoplakia and actinic cheilitis were present in less than $5 \%$ of the findings, corresponding to $2.6 \%$ of the white-colored alterations found. Conclusion: The patients in this stomatology service had high prevalence of alterations in oral mucosa, among them white lesions. Ethical Appreciation Certificate $\mathrm{n}^{\circ}$ 38861314.3.0000.5020.
\end{abstract}

Keywords: oral manifestations, mouth mucosa, prevalence.

\section{INTRODUCTION}

Oral health is considered part of systemic health and cannot be approached in isolation (1). This holistic view resulted in greater attention to the association between oral conditions and systemic diseases (2). The soft tissues of the oral cavity can be affected by a variety of pathologies, some without pathological significance and others that can compromise the patient's general health condition. The diagnosis of these changes by the professional is essential, and it is his responsibility to know the fundamental lesions, because through these he will be able to formulate the diagnostic hypotheses according to the history of the disease and the clinical characteristics of the lesion present at the time of the examination $(3,4,5)$.

Among the oral lesions, those that present a white or yellow-white coloration are the result of several factors, such as fungal colonization, reduced vascularization of connective tissues or deposition of a thick keratinized layer. A thorough investigation aiming at an early diagnosis is essential, since white colored lesions may represent variations of normality such as linea alba and leukoedema or lesions with high malignant potential such as leukoplakia, lichen planus and actinic cheilitis $(6,7)$.

The identification and detection of lesions are an important factor for the general health of the patient, from preventive measures to the fight against oral cancer and improving patient survival (8-11). Depending on the systemic condition and the medications used, an individual may develop more or less oral changes, so the knowledge of these factors can help the professional to plan a correct and appropriate therapeutic conduct for each individual $(1,2)$.

Regardless of the specialty, it is the Dentist's responsibility to examine the oral cavity and its related structures (11). In view of this, the objective was to study the main changes in the oral mucosa found in patients treated at a specific Stomatology Clinic, aiming to define the profile of this population and the implementation of preventive measures for oral cancer.

\section{MATERIAL AND METHODS}

This epidemiological, observational, retrospective and descriptive study was conducted in the city of Manaus, Amazonas, Brazil, by the School of Dentistry of the Federal University of Amazonas. The sample was composed by patients attended by the Curricular Extension Activity entitled "Stomatology: preventing, diagnosing and treating", over 18 years of age and of both sexes, had their medical records analyzed for presence changes in soft tissues, with emphasis on white colored lesions in the buccal mucosa region, during the period between 2010 to 2013. The variables age, gender, ethnicity, presence 
of deleterious habits, systemic diseases and use of medication, as well as how the injuries registered in the soft tissue evaluation form of the Faculty of Dentistry were registered in research collection forms. The collected data were tabulated and analyzed using descriptive and inferential statistics. Approval was obtained from the Human Research Ethics Committee of the Federal University of Amazonas under Certificate of Presentation for Ethical Appreciation $n^{\circ}$ 38861314.3.0000.5020.

\section{RESULTS}

From 2010 to 2013, 102 patients were treated at the Stomatology service. 82 patients were included in the study, according to the pre-defined inclusion criteria, where $50(60.98 \%)$ were from female and 32 $(39.02 \%)$ were from male. The age of the population studied ranged between 18 and 77 years, with an average of 43.3 years. Taking into account the marital status, $46.36 \%$ reported being single, $35.7 \%$ married or in a stable relationship, $10.98 \%$ divorced and $7.31 \%$ widowed.

Among the 82 patients, 46 reported having some type of systemic disease, where $24.39 \%$ were hypertensive and $9.76 \%$ were diabetic. 40 patients used some medication and were under regular medical monitoring. Of those affected by autoimmune diseases, a percentage of $9.76 \%$ was reported, being $100 \%$ female. Regarding deleterious habits, $15.85 \%$ $(\mathrm{n}=13)$ admitted having already used alcoholic beverages and $10.98 \%(n=9)$ reported being smokers, with the concomitant use of these being reported by $20.73 \%(n=17)$ of the patients.

As for the frequency of findings in the oral examination, 307 changes in total were found, and of these, $83(27.69 \%)$ were white-colored lesions. $90.24 \%$ of individuals $(n=74)$ had one or more white lesions. The presence of lesions was more evident in female patients (46.58\%). Most of the oral changes found in this study were considered as normality variations $(46.58 \%)$ or reactive lesions $(11.07 \%)$. Of the 83 white lesions found, only $8(2.6 \%)$ were lesions with malignancy potential.

Delimiting the sites of involvement of the various oral changes found, the tongue was the most affected site $(25.73 \%)$, followed by lip $(22.15 \%)$ and buccal mucosa (19.22\%). As for sites of involvement by strictly white lesions, the buccal mucosa was the site of highest prevalence of findings (45.88\%), followed by lip (25.88\%), tongue and labial mucosa (9.41\%). Coated tongue was the most commonly found oral alteration $(n=41,50 \%)$, followed by melanin pigmentation $(48.78 \%)$ and Fordyce granules (35.37\%). The other normality changes found were described in Table 1, while the most prevalent pathological changes were described in Table 2.

There were 27 reports of biopsied patients when there was no diagnostic conclusion with the clinical findings alone, and of these, all lesions with malignant

Table 1. Distribution of changes in the oral mucosa within the normal range in relation to sex.

\begin{tabular}{|c|c|c|c|c|c|c|}
\hline \multirow{3}{*}{$\begin{array}{l}\text { CHANGES IN THE } \\
\text { ORAL MUCOSA }\end{array}$} & \multicolumn{2}{|c|}{ FEMALE } & \multicolumn{2}{|c|}{ MALE } & \multicolumn{2}{|c|}{ TOTAL } \\
\hline & \multicolumn{2}{|c|}{$(n=50,60.98 \%)$} & \multicolumn{2}{|c|}{$(\mathrm{n}=32,39.02 \%)$} & \multicolumn{2}{|c|}{$(\mathrm{n}=82,100 \%)$} \\
\hline & $\mathbf{n}$ & $\%$ & $\mathbf{n}$ & $\%$ & $\mathbf{n}$ & $\%$ \\
\hline Coated tongue & 21 & 51.22 & 20 & 48.78 & 41 & 50.00 \\
\hline Melanin pigmentation & 23 & 57.50 & 17 & 42.50 & 40 & 48.78 \\
\hline Fordyce granules & 19 & 65.52 & 10 & 34.48 & 29 & 35.37 \\
\hline Sublingual varices & 12 & 60.00 & 8 & 40.00 & 20 & 24.39 \\
\hline Linea alba & 8 & 61.54 & 5 & 38.46 & 13 & 15.85 \\
\hline Torus & 4 & 66.67 & 2 & 33.33 & 6 & 7.32 \\
\hline Fissured tongue & 2 & 33.33 & 4 & 66.67 & 6 & 7.32 \\
\hline Leukoedema & 1 & 33.33 & 2 & 66.67 & 3 & 3.66 \\
\hline Geographic tongue & 1 & 33.33 & 2 & 66.67 & 3 & 3.66 \\
\hline Hairy tongue & 2 & 100 & - & - & 2 & 2.44 \\
\hline
\end{tabular}


Table 2. Distribution of pathological changes found in the oral mucosa in relation to sex.

\begin{tabular}{|c|c|c|c|c|c|c|}
\hline \multirow[t]{2}{*}{$\begin{array}{l}\text { DIAGNOSTIC } \\
\text { HYPOTHESIS }\end{array}$} & \multicolumn{2}{|c|}{$\begin{array}{c}\text { FEMALE } \\
(\mathrm{n}=\mathbf{5 0}, \mathbf{6 0 . 9 8 \%})\end{array}$} & \multicolumn{2}{|c|}{$\begin{array}{c}\text { MALE } \\
(n=32,39.02 \%)\end{array}$} & \multicolumn{2}{|c|}{$\begin{array}{c}\text { TOTAL } \\
(\mathrm{n}=\mathbf{8 2}, \mathbf{1 0 0 \%})\end{array}$} \\
\hline & $\bar{n}$ & $\%$ & n & $\%$ & n & $\%$ \\
\hline Denture stomatitis & 8 & 66.67 & 4 & 33.33 & 12 & 14.63 \\
\hline Scalloped tongue & 7 & 63.64 & 4 & 36.36 & 11 & 13.41 \\
\hline Aphthous ulcer & 7 & 70.00 & 3 & 30.00 & 10 & 12.20 \\
\hline Frictional hyperkeratosis & 6 & 75.00 & 2 & 25.00 & 8 & 9.76 \\
\hline Inflammatory fibrous hyperplasia & 4 & 57.14 & 3 & 42.86 & 7 & 8.54 \\
\hline Mucocele & 2 & 33.33 & 4 & 66.67 & 6 & 7.32 \\
\hline Traumatic ulcer & 4 & 66.67 & 2 & 33.33 & 6 & 7.32 \\
\hline Morsicatio Buccarum & 5 & 100 & - & - & 5 & 6.10 \\
\hline Angular cheilitis & 2 & 40.00 & 3 & 60.00 & 5 & 6.10 \\
\hline Lichen planus & 2 & 50.00 & 2 & 50.00 & 4 & 4.88 \\
\hline Papilloma & 2 & 66.67 & 1 & 33.33 & 3 & 3.66 \\
\hline Pyogenic granuloma & 2 & 66.67 & 1 & 33.33 & 3 & 3.66 \\
\hline Abscess/Fistula & 1 & 33.33 & 2 & 66.67 & 3 & 3.66 \\
\hline Granuloma & 1 & 50.00 & 1 & 50.00 & 2 & 2.44 \\
\hline Leukoplakia & 1 & 50.00 & 1 & 50.00 & 2 & 2.44 \\
\hline Hemangioma & 1 & 50.00 & 1 & 50.00 & 2 & 2.44 \\
\hline Actinic cheilitis & - & - & 2 & 100 & 2 & 2.44 \\
\hline Herpes & - & - & 1 & 100 & 1 & 1.22 \\
\hline Fibrous hyperplasia & 1 & 100 & - & - & 1 & 1.22 \\
\hline Candidiasis & 1 & 100 & - & - & 1 & 1.22 \\
\hline Squamous cell carcinoma & 1 & 100 & - & - & 1 & 1.22 \\
\hline Contact stomatitis & 1 & 100 & - & - & 1 & 1.22 \\
\hline Nicotine stomatitis & 1 & 100 & - & - & 1 & 1.22 \\
\hline
\end{tabular}

potential were confirmed after a histopathological examination. Of the disorders with malignant potential found in patients $(\mathrm{n}=8,10.81 \%)$, lesions such as leukoplakia and actinic cheilitis $(\mathrm{n}=2,2.44 \%$ each), and lichen planus $(\mathrm{n}=4,4.88 \%)$ were diagnosed. Associating the risk factors such as alcoholism and smoking with the finding of these 8 lesions with malignant potential, a total of 4 were present in the oral cavity of patients who reported using alcohol and cigarettes concomitantly, 3 in alcohol users only and only 1 in a patient who denied deleterious habits.

In the present study, there was no significance of higher prevalence of injuries among patients who used medication or not, and from the medical records analyzed, $100 \%$ of the patients reported having already used alcohol and cigarettes.

\section{DISCUSSION}

Research on oral lesions in different regions characterizes the populations and identifies the needs of each one of them, helping to plan health promotion, prevention and treatment actions. White lesions represent a broad spectrum of lesions of varying etiology, ranging from benign reactive lesions to dysplasia and carcinomas. Although there are classic characteristics that help to distinguish between them, some similarities may hinder diagnosis, thus requiring an appropriate clinical approach to exclude the possibility of malignancy (7).

The present study evaluated the dental records of 82 patients, where 307 lesions or normality variations were detected, 83 of which $(27.69 \%)$ 
were characterized as white lesions. Regarding gender, women were more affected by the lesions, as they represented $58.73 \%$ of the sample, similarly to the findings of Dogenski et al., who showed the prevalence in $56 \%$ of their sample (12). Some possible explanations for this result can be found in the increased demand for health services by women; however, associations with factors common to one gender can be accepted, since oral mucosa is sensitive to several systemic changes, whether physiological, metabolic or hormonal $(12,13)$.

Considering the age in relation to the occurrence of alterations, the population aged 54 years or older presented the highest number of findings $(n=102)$, corroborating the study by Rampi et al., where lesions were more prevalent in the sixth decade of life (47.2\%) (14). This result, however, disagrees with the study of oral lesions by Orakzai and Pontes et al., conducted in Pakistan and South Africa, respectively, which showed a prevalence of oral lesions in the third and fourth decade of life ( $63.2 \%$ and $21 \%$, respectively) $(15,16)$. The literature shows that individuals from the fifth and sixth decades of life tend to be more susceptible to the development of oral lesions, since in aging there are factors associated with the appearence of systemic diseases, the presence of deleterious habits, the use of poorly adapted prostheses, changes in salivary flow, among others $(12,13,17)$.

Among patients with systemic diseases $(\mathrm{n}=46)$, hypertension was the most reported (24.39\%), followed by diabetes and autoimmune diseases (9.76\% each). $86.9 \%$ confirmed the use of medication and regular medical follow-up. In the study by Lopes et al., $21.18 \%$ of the patients were hypertensive and $8.47 \%$ diabetic, however, $82.20 \%$ said they used some type of medication, but only $1.7 \%$ had medical follow-up, revealing, unlike this study, low adherence to treatment by patients (18). The present study did not show significance of a higher prevalence of injuries in patients with systemic diseases or who used medication, in the same way as the study of Robledo-Sierra et al., (19).

Of the main sites affected by oral changes in general, the tongue was the most frequent, representing $25.73 \%$ of the cases. Similarly, coated tongue was the most commonly found oral alteration (50\%), a finding similar to that of the study by Dogenski et al., (12).
It is associated with poor oral hygiene, reflecting a condition related much more to self-care than a significant change. The other frequently affected sites were the lip (22.15\%) and buccal mucosa (19.22\%), together with the most prevalent oral changes related to these, such as melanin pigmentation $(48.78 \%)$ and Fordyce granules (35.37\%), findings similar to those of the studies by Kansky et al., and Kniest et al., $(20,21)$. It is worth noting that some oral changes tend to be predilected by individuals from certain ethnic groups, as in the case of melanin pigmentation, which was present in $48.78 \%$ of cases in this study, since $76.83 \%$ of patients declared themselves brown.

Taking into account sites strictly affected by white lesions, the buccal mucosa was the most prevalent $(45.88 \%)$, as in the studies by Simi et al. and Ghosh et al., which showed this condition in about $76 \%$ and $19.5 \%$ of patients, respectively $(22,23)$. The most frequent white lesions found in the patients in this study were Fordyce granules $(35.37 \%)$, linea alba $(15.85 \%)$ and frictional hyperkeratosis $(9.76 \%)$, respectively, which corroborate with the prevalent lesions from the study by Kansky et al., (20). The presence of these white lesions at these sites is justified due to the prevalence of Fordyce granules, frictional hyperkeratosis, leukoedema, linea alba and lichen planus, which have their main location in the jugal mucosa. The lip (25.88\%), tongue and labial mucosa $(9.41 \%)$ were also frequent sites of white lesions.

As for the white lesions with malignant potential, after histopathological examination, a total of 8 lesions representing less than $5 \%$ of the white lesions were diagnosed, a result similar to that of Bhatnagar et al. (10). Regarding the prevalence of the type of lesion with malignant potency, the most frequent were lichen planus (4.88\%), leukoplakia and actinic cheilitis $(2.44 \%$, each), a result similar to the findings in the studies of Rampi et al., Orakzai, Pontes et al. and Al-Maweri et al., which showed prevalence of these groups of potentially malignant lesions $(14,15,16,24)$.

Delimiting the lesions with malignant potential in relation to the variables of the study, it can be seen that patients aged $>54$ years were the most affected. Regarding gender, there was no predilection of potentially malignant lesions, with the exception of 
actinic cheilitis, which affected the entire male gender, in the same way as the studies of Rampi et al. and Maia et al. $(14,25)$. The presence of these lesions in the age range of highest prevalence of this study corroborates with the literature reporting a marked frequency in middle-aged individuals, between the fifth and sixth decades of life, according to Mortazavi et al. and Warnakulasuriya $(26,27)$. As for gender, currently the literature reports that there is a parity in the findings in both sexes, given the increased consumption of alcohol and tobacco by women, so that they are now being reached equally when compared to men (6). Regarding risk factors, there was a predominance of alcoholism and smoking reports associated with the presence of lesions with malignant potential $(50 \%)$, especially in the case of leukoplakia and prolonged exposure to sunlight, in cases of actinic cheilitis, corroborating with Maia et al. and Warnakulasuriya which showed such associations $(25,28)$.

In conclusion, it this study the most common white-colored alterations were found were Fordyce granules $(35.37 \%)$, linea alba $(15.85 \%)$, and frictional hyperkeratosis $(9.76 \%)$. The most prevalent pathological changes were lichen planus, leukoplakia, and actinic cheilitis, all of which were below $5 \%$. The most prevalent oral changes were coated tongue and melanin pigmentation, related to poor oral hygiene and racial characteristics, respectively, being classified as developmental changes or variations in normality.

Funded by: Conselho Nacional de Desenvolvimento Científico e Tecnológico

$(\mathrm{CNPq}-$ Brazil) and Universidade Federal do Amazonas (UFAM). Economical support received in the form of research grants.

The authors declare that there are no conflicts of interest.

Research funded by CNPq and UFAM (Brazil).

\section{Correspondencia:}

Etienny da Silva Arruda

Rua Pedro Fernandes, 375, Torre 2, apto 305, Residencial Piazza Boa Esperança. CEP.: 78068710 ,

Cuiabá, Mato Grosso, Brasil.

Correio eletrônico: etiennyarruda@hotmail.com

\section{REFERENCES}

1. Gallarreta FWM, Turssi CP, Palma-Dibb RG, Serra MC. Histórico de saúde: atenção a condições sistêmicas e suas implicações, sobretudo nos fatores de risco de cárie. Rev Odonto Ciênc. 2008; 23(2):192-196.

2. Buczynski AK, Castro GF, Souza IPR. Impacto da saúde bucal na qualidade de vida de crianças infectadas pelo HIV: revisão de literatura. Ciênc Saúde Colet. 2008; 13(6):1797-1805.

3. Raposo A, Monsalves MJ, Aravena P, Sanhueza A. Prevalencia de lesiones de la Mucosa Oral en el Hospital Hernán Henríquez Aravena de Temuco. Int J Morphol. 2011; 29(2):622-627.

4. Vieira-Andrade RG, Guimarães FFZ, Vieira CS, Freire STC, Ramos-Jorge ML, Fernandes AM. Oral mucosa alterations in a socioeconomically deprived region: prevalence and associated factors. Braz Oral Res. 2011; 25(5):393-400.

5. Tommasi MHM. Diagnóstico em Patologia Bucal. 4a edição. São Paulo: Elsevier; 2014.

6. Regezi JA, Sciubba JJ, Jordan RCK. Patologia Oral: Correlações Clinicopatológicas. 7a edição. Rio de Janeiro: Elsevier; 2017.

7. Mortazavi H, Safi Y, Baharvand M, Jafari S, Anbari F, Rahmani S. Oral White Lesions: an updated clinical diagnostic decision tree: An Updated Clinical Diagnostic Decision Tree. Dent J. 2019; 7(1):15.

8. Tarquinio SB, Oliveira LJ, Correa MB, et al. Factors associated with prevalence of oral lesions and oral self-examination in young adults from a birth cohort in Southern Brazil. Cad Saude Publica. 2013; 29(1):155164.

9. Ali M, Joseph B, Sundaram D. Prevalence of oral mucosal lesions in patients of the Kuwait University Dental Center. Saudi Dent J. 2013;25(3):111-118.

10. Bhatnagar P, Rai S, Bhatnagar G, Kaur M, Goel S, Prabhat M. Prevalence study of oral mucosal lesions, mucosal variants, and treatment required for patients reporting to a dental school in North India: In accordance with WHO guidelines. J Family Community Med. 2013; 20(1):41-48.

11. Hipolito RA, Martins CR. Prevalência de alterações da mucosa bucal em adolescentes brasileiros institucionalizados em dois centros de reeducação. Cienc Saude Col. 2010; 15(2):3233-3242.

12. Dogenski LC, Farina AP, Linden MSS, Trentin MS, Miyagaki DC, De Carli JP. Oral Lesions found in a Dental School in Southern Brazil. J Contemp Dent Pract. 2018; 19(9):1037-1041.

13. Torres SR, Souza NT, Romañach MJ, Cantisano MH, Luiz RR, Cardoso AS. Detection of oral mucosal lesions by screening examinations. J Oral Diag. 2020; 5(1):19.

14. Rampi PT, Gambin DJ, Leal LO, et al. Profile of 
Patients with White Lesions of the Oral Mucosa Treated at a Dental School in Southern Brazil. J Clin Diagn Res. 2019; 13(11):5-9.

15. Orakzai GS, Waqar-Un-Nisa, Orakzai SH. Oral white lesions - Histomorhological assessment and associated risk factors. J Ayub Med Coll Abbottabad. 2015; 27(4):865-8.

16. Pontes CC, Chikte U, Kimmie-Dhansay F, Erasmus RT, Kengne AP, Matsha TE. Prevalence of Oral Mucosal Lesions and Relation to Serum Cotinine Levels-Findings from a Cross-Sectional Study in South Africa. Int J Environ Res Public Health. 2020; 17(3): 1065 .

17. Zhou N, Zhang X, Yan JQ, Yu YQ, Cai Y. Prevalence of oral mucosal diseases in older adults in Mainland China: A meta-analysis of observational studies. Int $\mathrm{J}$ Environ Res Public Health. 2020; 17(6):1887.

18. Lopes MC, de Oliveira VM, Flório FM. Condição bucal, hábitos e necessidade de tratamento em idosos institucionalizados de Araras. Cien Saude Colet. 2010; 15(6):2949-54.

19. Robledo-Sierra J, Mattsson U, Svedensten T, Jontell M. The morbidity of oral mucosal lesions in an adult Swedish population. Med Oral Patol Oral Cir Bucal. 2013; 18(5):e766-72.

20. Kansky AA, Didanovic V, Dovsak T, Brzak BL, Pelivan I, Terlevic D. Epidemiology of oral mucosal lesions in Slovenia. Radiol Oncol. 2018; 52(3):263-266.

21. Kniest G, Stramandinoli RT, Ávilla LFC, Izidoro ACAS. Frequência das lesões bucais diagnosticadasno centro de especialidades odontológicas de Tubarão (SC). Rev Soc Bras Odonto. 2011; 8(1):13-18.
22. Simi SM, Nandakumar G, Anish TS. White lesions in the oral cavity: A clinicopathological study from a tertiary care dermatology centre in Kerala, India. Indian J Dermatol. 2013; 58:269-274.

23. Ghosh S, Pal S, Ghatak S, Saha S, Biswas S, Srivastava P. A clinicopathologic and epidemiologic study of chronic white lesions in the oral mucosa. Ear Nose Throat J. 2017; 96(8):E13-E17.

24. Al-Maweri SA, Al-Jamaei A, Saini R, Laronde DM, Sharhan A. White oral mucosal lesions among the Yemeni population and their relation to local oral habits. J Investig Clin Dent. 2018; 9(2):e12305.

25. Maia HC, Pinto NA, Pereira Jdos S, de Medeiros AM, da Silveira ÉJ, Miguel MC. Potentially malignant oral lesions: clinicopathological correlations. Einstein (Sao Paulo). 2016; 14(1):35-40.

26. Mortazavi H, Safi Y, Baharvand M, Jafari S, Anbari F, Rahmani S. Oral White Lesions: An updated clinical diagnostic decision tree. Dent J (Basel). 2019; 7(1):15.

27. Warnakulasuriya S. White, red, and mixed lesions of oral mucosa: A clinicopathologic approach to diagnosis. Periodontol 2000. 2019; 80(1):89-104.

28. Warnakulasuriya S. Clinical features and presentation of oral potentially malignant disorders. Oral Surg Oral Med Oral Pathol Oral Radiol. 2018; 125(6):582-590.

Recibido : 04-02-2021

Aceptado : 28-04-2021 